\title{
EFEKTIVITAS PEMBELAJARAN MATEMATIKA MELALUI PENERAPAN MODEL KOOPERATIF TIPE GROUP INVESTIGATION (GI) PADASISWA KELAS X SMA NEGERI 3 SIDRAP
}

\author{
Sri Satriani*, Siti Fahmia** \\ Universitas Muhammadiyah Makassar \\ srisatriani@unismuh.ac.id",mhiea.mickey@gmail.com**
}

\begin{abstract}
Abstrak: Penelitian ini merupakan penelitian pra-eksperimen yang melibatkan satu kelas sebagai kelas eksperimen dengan menggunakan desain eksperimen One-Group Pretest-Postest Design yang bertujuan untuk mengetahui keefektifan pembelajaran matematika melalui Model Kooperatif Tipe Group Investigation (GI) pada siswa kelas X SMA Negeri 3 Sidrap dengan sampel 32 orang siswa. Data dikumpul dengan menggunakan beberapa instrumen penelitian yaitu tes hasil belajar, lembar observasi dan angket. Selanjutnya data yang terkumpul telah dianalisis dengan menggunakan analisis statistik deskriptip dan analisis statistik inferensial. Hasil belajar matematika siswa kelas X IIS 2 SMA Negeri 3 Sidrap setelah diterapkan Model Kooperatif Tipe Group Investigation (GI) mengalami peningkatan dengan nilai gain ternormalisasi berada pada interval $g \geq 0,7$ yang menandakan bahwa peningkatan hasil belajar yang terjadi dikategorikan tinggi. Aktivitas siswa yang berkaitan dengan kegiatan pembelajaran dari aspek yang diamati secara keseluruhan dikategorikan aktif. Hal ini ditunjukkan dengan perolehan rata-rata persentasi aktivitas siswa yaitu sebanyak $81,47, \%$ aktif dalam pembelajaran matematika.
\end{abstract}

Kata Kunci: efektivitas pembelajaran matematika; Group Investigation(GI).

\section{PENDAHULUAN}

Peran pendidikan sangat penting untuk menciptakan masyarakat yang cerdas, terbuka, dan demokratis. Oleh karena itu pembaharuan dalam bidang pendidikan harus selalu dilakukan untuk meningkatkan kualitas pendidikan suatu bangsa. Namun untuk mewujudkan tujuan pendidikan tersebut, diperlukan usaha untuk meningkatkan proses pembelajaran agar diperoleh hasil yang efektif dan efisien. Dari sini pendidikan tidak hanya outputnya, melainkan harus dilihat juga dari segi bagaimana proses pembelajaran itu diselenggarakan yang membutuhkan perencanaan dan pelaksanaan yang sangat matang agar tercapai hasil yang maksimal.Salah satu caranya adalah dengan menerapkan model pembelajaran yang dapat menarik minat belajar siswa di dalam kelas. Penentuan model pembelajaran sangat penting dalam menyelenggarakan proses belajar mengajar. Dengan merumuskan model pembelajaran akan menentukan (1) pola interaksi kegiatan belajar mengajar, (2) tahaptahap pencapaian tujuan pengajaran, dan (3) tingkat serta hasil belajar.

Berdasarkan observasi dan wawancara yang dilakukan oleh peneliti di SMA Negeri 3 Sidrap, 
diperoleh informasi yaitu sebagian guru matematika jarang memberikan kesempatan kepada siswa untuk belajar berkelompok, jarang memberikan kesempatan pada siswa untuk menyimpulkan sendiri materi yang dibahas oleh guru, sehinga terkadang siswa berpedoman pada 3D, yaitu datang, duduk, diam, terlebih lagi jika pelajaran matematika ditempatkan pada jam terakhir. Selain itu kurang terjadi interaksi antar siswa karenadalam proses pembelajaran siswa tidak diorganisasikan ke dalam kelompokkelompok belajar sehingga siswa sulit untuk saling bertukar informasi/pengetahuan dalam proses pembelajaran sehingga siswa dalam mengikuti pelajaran menjadi tidak efektif dan tujuan pembelajaran akhirnya tidak tercapai dan prestasi belajar siswa di bawah kritria ketuntasan minimal yang berlaku oleh sekolah tersebut yaitu 75. Khususnya

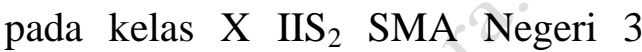
Sidrap. Ketidaktercapaian tujuan pembelajaran matematika tidak hanya disebabkan oleh faktor siswanya saja, faktor dari gurupun ikut menyebabkan nya. salah satu upaya untuk meningkatkan prestasi belajar siswa adalah dengan melakukan pembaharuan dalam pengajaran matematika di Sekolah yaitu pembaharuan strategi pengajaran kegiatan belajar, model mengajar dalam mata pelajaran Matematika dapat dipilih dari sekian banyak model yang tersedia. Para guru hendakanya memiliki kempuan dalam memilih model yang tepat untuk setiap materi pelajaran dan bahkan untuk mencapai tujuan pembelajaran.

Dalam proses belajar mengajar terdapat berbagai komponen yang saling berkaitan seperti tujuan materi/bahan pelajaran, kegiatan belajar mengajar. Model kooperatif tipe, alat/media, sumber belajar dan evaluasi. Dari komponen tersebut harus dikusai benar oleh guru, hal ini bertujuan utuk meningkatkan kemampuan guru dalam melaksanakan proses belajar mengajar. Salah satu ciri terbentuknya proses belajar mengajar yang baik dan efektif yaitu adanya variasi model kooperatif tipe mengajar. Variasi dalam pembelajaran adalah perubahan dalam proses kegiatan yang bertujuan untuk meningkatkan motivasi belajar peserta didik, serta mengurangi kejenuhan dan kebosanan (Mulyasa, 2011:78). Dalam pengajaran matematika, model kooperatif tipe pendekatan serta model yang telah dipilih, merupakan alat komunikasi yang baik antara pengajar dengan siswa, sehingga setiap pengajaran dan setiap uraian yang disajikan dapat memberikan motivasi belajar dengan menemukan model kooperatif tipe dan pendekatan serta model yang dipilih dalam pembelajaran matematika nantinya akan membawa pengaruh yang baik terhadap pola pengajaran maupun hasil akhir yang dicapai.

Salah satu model pembelajaran yang dapat digunakan untuk meningkatkan prestasi belajar siswa adalah dengan menerapkan Model Pembelajaran Group Investigation 
(GI). Dengan model pembelajaran ini minat belajar siswa meningkat dan hasil pembelajarannya diharapkan lebih bermakna bagi siswa.

Berdasarkan uraian di atas maka perlu diadakannya penelitian eksperimen dengan judul "Efektivitas Pembelajaran Matematika Melalui Penerapan Model Kooperatif Tipe Group Investigation (GI) Pada Siswa kelas X SMA Negeri 3 Sidrap. Adapun rumusan masalah dalam penelitian ini adalah "Apakah pembelajaran matematika efektif melalui penerapan model kooperatif tipe Group Investigation (GI) ditinjau dari indikator keefektifan pembelajaran yaitu: 1) Hasil belajar matematika siswa setelah diajar dengan menggunakan Model Kooperatif Tipe Group Investigation (GI), 2) Aktivitas siswa pada saat diajar dengan menggunakan Model Kooperatif Tipe Group Investigation (GI), dan 3) Respon siswa terhadap pembelajaran matematika dengan menggunakan Model Kooperatif Tipe Group Investigation (GI).

\section{TINJAUAN TEORETIS \\ Efektivitas Pembelajaran}

Efektivitas berasal dari kata efektif Menurut kamus Bahasa Indonesia (2012:203), efektif berarti; (1) ada efeknya; (2) ada pengaruhnya. (3) ada akibatnya: (4) dapat membawa hasil. Menurut Sadiman (Trianto, 2011:20) Mendefenisikan Keefektifan pembelajaran adalah hasil guna yang diproleh setelah pelaksanaan proses belajar mengajar. Keefektifan pembelajaran adalah keadaan yang menunjukkan sejauh mana hasil yang dicapai sesuai dengan tujuan yang telah direnacakan sebelumnya.

Mukhlis dalam Novita (2014: 133) menyatakan bahwa pembelajaran matematika dikatakan efektif jika paling sedikit tiga aspek dari empat aspek berikut ini terpenuhi, yaitu: (1) ketuntasan belajar, (2) aktivitas siswa dan (3) respons siswa, dengan syarat aspek ketuntasan belajar terpenuhi. Berikut empat indikator yang akan digunakan dalam penelitian ini.

a. Hasil belajar

Menurut Oemar Hamalik (Tampubolon. 2014:140) "Hasil belajar adalah perubahan tingkah laku siswa secara nyata setelah proses belajar mengajar yang sesuai dengan tujuan pengajaran. Sementara menurut Suprijono (Taufiq. 2014:4959) mengemukakan bahwa "Hasil belajar belajar adalah pola-pola perbuatan, nilai-nilai, pengertianpengertian, sikap-sikap, apresiasi, dan keterampilan". Sehingga dapat disimpulkan bahwa hasil belajar merupakan tingkat pencapaian seseorang dan perubahan tingkah laku, apresiasi, dan keterampilan siswa secara nyata setalah proses belajar mengajar yang sesuai dengan tujuan pengajaran.

Hasil belajar dapat dilihat dari ketuntasan hasil belajar siswa yang telah mencapai Kriteria Ketuntasan Minimal (KKM) sebagaimana ditetapkan oleh sekolah. Hasil belajar Matematika yang dimaksud adalah tingkat penguasaan siswa terhadap materi pelajaran setelah melalui proses pembelajaran matematika 
dengan Model Kooperatif Tipe Group Investigation.

Tingkat penguasaan siswa ini diukur dari nilai yang diperoleh siswa berdasarkan tes hasil belajar yang diberikan. Berdasarkan KKM yang ditetapkanSMA Negeri 3 Sidrap, bahwa seorang siswa dikatakan telah tuntas belajar jika hasil belajar siswa tersebut mencapai $\geq 75$, tuntas secara klasikal jika terdapat minimal $80 \%$, dan hasil belajar siswa dikatakan efektif jika rata-rata gain ternormalisasi siswa minimal berada dalam kategori sedang atau > 0,29. Ketuntasan belajar dapat dilihat dari hasil belajar yang telah mencapai ketuntasan individual, yakni siswa telah memenuhi kriteria ketuntasan minimal.

b. Aktivitas Siswa

Aktivitas belajar siswa adalah aktivitas yang bersifat fisik ataupun mental (Sardiman, 2005:96). Aktivitas belajar adalah serangkaian kegiatan fisik atau jasmani maupun mental atau rohani yang saling berkaitan sehingga tercipta belajar yang optimal. Dalam aktivitas belajar ini peserta didik haruslah aktif mendominasi dalam mengikuti proses belajar mengajar sehingga mengembangkan potensi yang ada pada dirinya. Dengan kata lain dalam beraktivitas peserta didik tidak hanya mendengarkan dan mencatat seperti yang dijumpai di sekolah-sekolah yang melakukan pembelajaran secara konvensional.

Proses pembelajaran dikatakan efektif bila peserta didik secara aktif ikut terlibat langsung dalam pengorganisasian dan penemuan informasi (pengetahuan), sehingga mereka tidak hanya menerima secara pasif pengetahuan yang diberikan oleh guru.

c. Respon Siswa Terhadap Pembelajaran

Respons siswa adalah tanggapan siswa terhadap pelaksanaan pembelajaran matematika setelah Model Pembelajaran Kooperatif Tipe Group Investigation (GI) diterapkan pada siswa. Model pembelajaran yang baik dapat memberi respons yang positif bagi siswa setelah mereka mengikuti kegiatan pembelajaran.

\section{Model Pembelajaran Kooperatif Tipe Group Investigation (GI)}

Model Pembelajaran Kooperatif Tipe Group Invstigtion(GI) adalah bentuk pembelajaran kooperatif yang bersasal dari jamannya Jhon Dewey (1970), tetapi telah diperbaharui oleh Shlomo dan Yael Sharan, serta Rachel di Israel (Slavin, 2016 : 214).

Group Investigation

merupakan salah satu bentuk model pembelajaran kooperatif yang menekan pada partisipasi dan aktivitas siswa untuk mencari sendiri materi (informasi) pelajaran yang akan dipelajari melalui berbagai sumber dari dalam luar sekolah. Siswa dilibatkan sejak perencanaan, baik dalam menentukan topik maupun cara untuk mempelajarinya melalaui investigasi.

(Slavin, 2016: 218-220) membagi langkah-langkah pelaksanaan model Group Investigasi (GI) meliputi 6 fase, yaitu : Tahap 1: mengidentifikasi topik dan mengatur 
murid kedalam kelompok. Tahap 2: merencanakan tugas yang akan dipelajari. Tahap 3: melaksanakan investigasi. Tahap 4: menyiapkan laporan akhir. Tahap 5: mempresentasikan laporan akhir. Tahap 6: evaluasi.

\section{METODOLOGI PENELITIAN}

Jenis penelitian ini adalah preexperimental dengan melibatkan satu kelompok atau satu kelas. Dengan tujuan untuk mengetahui gambaran efektivitas pembelajaran matematika melaui Model Pembelajaran Kooperatif Tipe Group Investigation (GI) padasiswa kelas $\mathrm{X}$ IIS $_{2}$ SMA Negeri 3 Sidrap.

Desain pada penelitian ini adalah One Group Pretest-Postest Design yaitu sebuah eksperimen yang dilaksanakan tanpa adanya kelompok pembanding (kontrol) dengan memberikan pretest dan postest di samping perlakuan.

Dalam penelitian ini peneliti menetapkan populasi yang akan dijadikan objek penelitian yaitu seluruhsiswa kelas $\mathrm{X} \quad \mathrm{IIS}_{2} \quad \mathrm{SMA}$ Negeri 3 Sidrap tahun pelajaran 2017/2018. Pengambilan sampel dalam penelitian ini yaitu dengan random sampling dengan cara : 1) Membuat kerangka sampling dengan kelas sebagai unit sampel, 2) Memilih salah satu kelas, dari kelas yang ada, 3) Siswa yang terlibat dalam kelas tersebut merupakan sampel dalam peneltian ini.

Adapun tahap-tahap prosedur peneltian ini adalah sebagai berikut :

1. Tahap Persiapan: Adapun kegiatan yang dilakukan dalam tahap persiapan ini adalah sebagai berikut: a) Menelaah kurikulum , b) Menelaah materi yang akan diajarkan, c) Membuat rencana pelaksanaan pembelajaran (RPP) Model Kooperatif Tipe Group Investigation (GI), 4) Membuat lembar observasi siswa untuk melihat aktivitas siswa saat proses belajar mengajar berlangsung, 5) Membuat angket respons siswa. mengenai tanggapan siswa tentang kegiatan pembelajaran melalui penerapan Model Kooperatif Tipe Group Investigation (GI), 6) Membuat pretest dan posttest sesuai materi yang akan diajarkan.

2. Tahap Pelaksanaan Kegiatan: Tahap pelaksanaan Kegiatan pelaksanaan dalam tahap ini adalah pelaksanaan proses pembelajaran sesuai dengan rencana pembelajaran. Adapun langkahlangkah pada tahap ini adalah: a) Menyampaikan materi yang akan diajarkan dengan menggunakan pembelajaran kooperatif tipe Group Investigation (GI) sesuai dengan Rencana Pelaksanaan Pembelajaran (RPP), Memberikan Pretest dan Posttest untuk mengetahui hasil belajar siswa,c) Memberikan angket respons siswa mengenai tanggapan siswa tentang kegiatan pembelajaran melalui penerapan Model Kooperatif Tipe Group Investigation (GI).

3. Tahap Akhir: Kegiatan yang dilakukan pada tahap akhir adalah:Mengolah data hasil penelitian, membahas data hasil 
penelitian dan menyimpulkan hasil penelitian.

Instrumen yang digunakan dalam penelitian ini adalah:

1. Tes hasil belajar

Tes hasil belajar merupakan bentuk uraian untuk memproleh data sejauh mana penguasaan matematika siswa setelah proses pembelajaran. Penskoran hasil tes siswa menggunakan skala bebas yang bergantung dari bobot butir soal.

2. Lembar observasi (pengamatan).

Lembar observasi adalah instrumen yang digunakan untuk memperoleh data tentang aktivitas siswa dan keterlaksanaan pembelajaran selama proses pembelajaran matematika.

3. Angket respon siswa

Angket respon siswa untuk memproleh data tentang tanggapan siswa terhadap pembelajaran yang dilakukan melalui penerapan model Group Investigation (GI).

Adapun teknik pengumpulan data dalam penelitian ini adalah sebagai berikut:

1. Untuk memproleh data mengenai hasil belajar matematika siswa, peneliti menggunakan tes.

2. Untuk memproleh data mengenai aktivitas siswa selama proses pembelajaran penelti menggunakan tehnik observasi atau pengamatan

3. Untuk memproleh data mengenai respons siswa terhadap pembelajaran peneliti menggunakan tehnik pemberian angket.

Data yang telah terkumpul dengan menggunakan instrumen- instrumen yang ada, kemudian dianalisis dengan menggunakan teknik analisis deskriptif dan analisis inferensial.

\section{HASIL DAN PEMBAHASAN}

Hasil penelitian yang telah dikumpulkan kemudian dianalisis dengan menggunakan tehnik analisis statistik deskriptif dan analisis statistik inferensial. Hasil belajar siswa kelas $\mathrm{X}$ IIS 2 SMA Negeri 3 Sidrap dapat dilihat dari ketuntasan KKM yang dicapai siswa sesuai dengan yang ditetapkan sekolah yaitu 75 .

Secara deskriptif, hasil belajar matematika siswa kelas X IIS ${ }_{2}$ SMA Negeri 3 Sidrap setelah penerapan model GI dalam kategori sangat rendah dengan skor rata-rata hasil belajara 25,96. Dari 32 orang siswa tidak ada memenuhi KKM yang telah ditetapakan artinya 0\% siswa yang tuntas secara klasikal. Setelah penerapan model GI skor rata-rata hasil belajar siswa kelas X IIS 2 SMA Negeri 3 Sidrap adalah 80,82 dengan skor tersebut, hasil belajar matematika siswa dalam kategori tinggi, dai 32 orang siswa terdpat 29 orang siswa yang memenuhi KKM, artinya $90,62 \%$ siswa yang memenuhi ketuntasan secara klasikal. Dengan hasil demikian setelah penerapan model GI, hasil belajar matematika siswa mengalami peningkatan (Gain), yakni dari kategori sangat rendah kekategori tinggi dengan skor ratarata hasil belajar 25,96 ke 80,82. Skor rata-rata peningkatan hasil belajar matematika siswa adalah 0,74 . Skor tersebut menunjukkan bahwa 
peningkatan hasil belajar matematika siswa dalam kategori tinggi dengan rentan skor $g \geq 0,7$.

Hal ini sesuai dengan penelitian yang dilakukan oleh Wahyuni Yaman pada tahun 2015 dengan judul "Efektivitas pembelajaran Matematika melalui penerapan model kooperatip tipe Group Investigation (GI) pada siswa kelas VII SMP Jaya Negara Makassar" diperoleh hasil bahwa model GI efektif di terapkan dalam pembelajaran matematika dilihat dari 22 orang siswa yang mengikuti tes hasil belajar 86,36\% siswa masuk dalam kategori tuntas.

Hasil analisis inferensial menunjukkan bahawa data pretest dan postest telah memenuhi uji normalitas yang meupakan uji prasyarat sebelum melakukan uji hipotesis data pretest dan postest telah terdistribusi dengan normal karena nilai $\mathrm{P}>a(a=0,05)$ karena data berdistribusi normal maka memenuhi kriteria untuk digunakan uji $T$, dalam menguji hipotesis penelitian. Pengujian KKM dan gain menggunakan uji $T$, Untuk KKM dengan hipotesis statistik $\mathrm{H}_{0}: \mu \leq 74,9$ melawan $\mathrm{H}_{1}: \mu>74,9$ diperoleh hasil $\mathrm{P}_{\text {Value }}=0,000<\alpha=0,05$ memberikan kesimpulan bahwa $\mathrm{H}_{0}$ ditolak dan pada saat yang bersamaan $\mathrm{H}_{1}$ diterima. Dengan demikian rata-rata skor posttest siswa kelas X IIS 2 SMA Negeri 3 sidrap setelah mengikuti pembelajaran matematika dengan Model Pembelajaran Kooperatif Tipe Group Investigation lebih besar daripada kriteria ketuntasan minimal (KKM) yaitu 75.

Untuk Uji hipotesis berdasarkan gain dengan hipotesis statistik $\mathrm{H}_{0}: \mu_{\mathrm{g}}$ $\leq 0,29$ melawanH $_{1}: \mu_{\mathrm{g}}>0,29$ diperoleh hasil $\mathrm{P}_{\text {Value }}=0,000<\alpha=0,05$ Dengan demikian rata-rata peningkatan nilai hasil belajar siswa kelas X IIS 2 SMA Negeri 3 sidrap setelah mengikuti pembelajaran matematika dengan Model Pembelajaran Kooperatif Tipe Group Investigation lebih besar dari kriteria yang telah ditentukan yaitu 0,30 .

Untuk uji hipotesis berdasarkan ketuntasan klasikal dengan hipotesis statistik $\quad H_{0}: \pi \leq 79,9 \%$ lawan $H_{1}: \pi>79,9 \%$ yang dilakukan dengan uji proporsi (uji Z) diperoleh nilai $Z_{\text {hitung }}=1,96>1,64 Z_{\text {tabel }}=0,45$, berarti $\mathrm{Z}_{\text {hitung }}>\mathrm{Z}_{\text {tabel }}$ yang berarti hasil belajar siswa tuntas secara klasikal.

Adapun indikator keberhasilan siswa dalam penelitian ini ditunjukkan dengan skor sekurang kurangnya terlibat aktif dalam proses pembelajaran melalui penerapan model GI, dari hasil peneltian diproleh dari hasil observasi, menunjukkan bahwa dari 32 orang atau $100 \%$ siswa yang mengikuti kegiatan pembelajaran terdapat $81,47 \%$ dari jumlah siswa aktif pada kegiatan pembelajaran pada semua pertemuan. Dengan demikian keaktivan siswa untuk setiap pertemuan telah mencapai kriteria yang diharapkan yaitu $75 \%$ dari jumlah siswa terlibat aktif dalam kegiatan pembelajaran. Gambaran keaktifan siswa selama proses pembelajaran melalui penerapan GI, dapat dilihat dari uraian indikator berikut, pada indikator pertama yaitu kehadiran siswa secara umum keaktifan siswa mengikuti proses 
belajar mengajar tidak mengalami masalah, hanya pada pertemuan ke empat terdpat 2 orang siswa yang tidak mengikuti proses belajar, karena tidak hadir.pada indikator kedua, belum sepenuhnya siswa yang memperhatikan materi oleh karena pergantian guru yang mengajar yang mengakibatkan siswa cenderung cuek, akan tetapi setelah penerapan GI, perlahan siswa mulai tertarik dan siswa mulai mengikuti materi.

Pada indikator ke tiga tidak semua siswa aktif dalam kelompoknya masing-masing, dikarenakan beberapa siswa cenderung mengandalkan teman sekelompoknya. Pada indikator keempat dan kelima yaitu mengajukan dan menjawab pertanyaan masih tergolong rendah, karena kegiatan ini didominasi oleh siswa yang dalam kategori pandai. pada indikator keenam dan ketujuh hampir semua siswa mengerjakan LKS dan PR karena siswa cenderung bekerja sama dalam menyelesaikan tugas dengan teman sekelompoknya. Dan untuk indikator kedelapan hanya beberapa orang yang tidak melakukan aktivitas di luar skenario pembelajaran.

Hasil analisis deskriptif data respons siswa setelah mengikuti pembelajaran matematika dengan Model Pembelajaran Kooperatif Tipe Group Investigation yang telah diuraikan pada bagian sebelumnya menunjukkan bahwa dari 32 orang atau $100 \%$ siswa yang mengisi angket respon siswa terdapat $88,12 \%$ di antaranya memberikan respon positif terhadap pembelajaran matematika dengan Model Pembelajaran Kooperatif Tipe Group Investigation. Dengan demikian persentase siswa yang memberi respons positif berada di atas kriteria persentase yang telah ditentukan yaitu $75 \%$ dari jumah siswa yang mengisi angket respon siswa memberi respons positif.

Secara umum siswa memberikan respons positif mengaku senang mengikuti pembelajaran berkelompok karena dalam pembelajaran berkelompok mereka dapat berdiskusi dan bertukar pendapat dengan teman-teman sekelompoknya. Alasan yang tidak kalah menarik adalah seorang siswa mengaku senang belajar berkelompok karena semua anggota kelompok dapat memahami materi secara bersamaan. Artinya kondisi sosial dalam pembelajaran berkelompok dapat terjalin harmonis. Sementara itu siswa yang memberikan respon negatif mengaku tidak senang belajar berkelompok karena tidak senang bekerja sama. Di samping itu terdapat siswa yang mengaku hanya dirinya saja yang bekerja dalam kelompoknya. Tidak terjalin kerjasama yang baik dengan temantemannya. Pada aspek apakah anda senang belajar matematika dengan menuliskan pertanyaan, 78,12\% siswa memberikan respons positif. Pada umumnya alasan siswa memberikan respons positif karena dengan pembelajran Model Kooperatif Tipe Group Investigtion memudahkan siswa saling bertukar pikiran dan bekerja sama pada saat diskusi dan pada saat mengerjakan soal. 
Pada aspek apakah anda mengalami ada kemajuan pada pembelajaran matematika dengan Model Pembelajaran Kooperatif Tipe Group Investigation $96,88 \%$ siswa memberikan respon positif. Alasan yang diungkapkan oleh seorang siswa yang mengatakan bahwa Pembelajaran Kooperatif Tipe Group Investigation merupakan pembelajaran yang bisa meningkatkan minat belajar. Siswa yang memberi respons negatif mengaku tidak begitu senang belajar berkelompok karena harus pindah dari posisi dudukya. Secara umum siswa setuju apabila pembelajaran berikutnya dilakukan dengan menerapkan Model Kooperatif Tipe Group Investigation. Menurut Sudjana (2014:21) bahwa kemampuan yang dituntut dalam pelaksanaan proses pembelajaran adalah keaktifan guru dalam menciptakan dan menumbuhkan kegiatan siswa untuk belajar sesuai dengan rencana yang telah disusun dalam perencanaan. Berdasarkan teori tersebut, tolak ukur kemampuan guru dalam mengelola pembelajaran berdasarkan keterlaksanaan dari RPP yang sesuai ketika diterapkan dalam pembelajaran. Dari treatment yang dilakukan selama 4 kali pertemuan, diamati oleh observer yakni seorang guru mata pelajaran matematika. Dari hasil penelitian diperoleh skor ratarata penilaian tentang kemampuan guru dalam mengelola pembelajaran dari pertemuan II, III, IV dan V secara berturut-turut adalah 2,27, $2,81,3,18,3,36$. Dan skor rata-rata keseluruhan penilaian dari 4 pertemuan tersebut adalah 2,90.

Berdasarkan tabel konversi nilai keterlaksanaan pembelajaran, skor yang diperoleh dalam kategori aktif dengan interval skor $1,50-2,90$. Artinya guru aktif dengan kemampuan yang dimiliki untuk mengelola pembelajaran matematika melalui penerapan Model Kooperatif Tipe Group Investigation pada siswa kelas X IIS 2 SMA Negeri 3 Sidrap.

\section{SIMPULAN DAN SARAN}

Berdasarkan hasil penelitian yang telah dikemukakan dapat disimpulkan bahwa:

1. Hasil belajar matematika siswa kelas X IIS 2 SMA Negeri 3 Sidrap setelah diterapkan Model Kooperatif Tipe Group Investigation (GI) mengalami peningkatan dengan nilai gain ternormalisasi berada pada interval $g \geq 0,7$ yang menandakan bahwa peningkatan hasil belajar yang terjadi dikategorikan tinggi.

2. Aktivitas siswa yang berkaitan dengan kegiatan pembelajaran dari aspek yang diamati secara keseluruhan dikategorikan aktif. Hal ini ditunjukkan dengan perolehan rata-rata persentasi aktivitas siswa yaitu sebanyak 81,47,\% aktif dalam pembelajaran matematika.

3. Hasil analisis respons siswa terhadap pembelajaran matematika melalui Pendekatan Group Investigation telah mencapai $\geq 75 \%$, yaitu rata-rata persentasi frekuensi siswa yang memberi jawaban YA atau respons positif 
adalah $88,12 \%$. Dengan demikian dapat disimpulkan bahwa siswa memberi respons positif terhadap pembelajaran matematika melalui Pendekatan Group Investigation.

Berdasarkan kesimpulan yang diperoleh dari penelitian ini, maka penulis mengajukan beberapa saran sebagai berikut :

1. Disarankan kepada guru yang ingin menerapkan Pendekatan Group Investigation agar mempertimbangkan materi dan kondisi siswa sehingga dapat terlaksana secara efektif.

2. Bagi peneliti yang berminat mengembangkan lebih lanjut penelitian ini diharapkan mencermati keterbatasan penelitian ini, sehingga penelitian selanjutnya dapat menyempurnakan hasil penelitian ini.

\section{DAFTAR PUSTAKA}

Agus, Susilo Farid, 2012. Peningkatan Efektivitas Pada Proses Pembelajaran. Artikel diterbitkan (Online), jur nalmahasiswa.unesa.ac.id/articl e/3022/30/article.pdf. Surabaya ,Universitas Negeri Surabaya.Diakses Tanggal 13 September 2017 Pukul 04:18 WITA

FKIP Unismuh Makassar. 2017. Pedoman Penulisan Skripsi. Makassar: Panrita Press.

Harmiati. 2016. Efektivitas Pembelajaran Matematika Melalui Penerapan Model Kooperatif Tipe Questions Student Have Pada Siswa Kelas Viii Smp Negeri 2 Duampanua Kabupaten Pinrang. Skripsi tidak diterbitkan. Makassar : FKIP Unismuh Makassar.

Lubis, 2009. Evaluasi Pendidikan Nilai. Yogyakarta:Pustaka Belajar.

Maryam, Ummu. 2015. Efektivitas Pembelajaran Matematika Melalui Penerapan Model Kooperatif Tipe Group Investigation (GI) Pada Siswa Kelas VII ${ }_{c}$ MTs Aisyiyah sungguminasa. Skripsi tidak diterbitkan. Makassar : FKIP Unismuh Makassar.

Mulyasa, E. 2011. Menjadi Guru Profesional. Bandung: Remaja Rosdakarya.

Novita, Rita, 2014. Efektivitas Model Pembelajaran Kooperatif Tipe Think Pair Share(Tps) pada Materi Trigonometri di Kelas XI IPA 1 SMA Negeri 8 Banda Aceh. Jurnal Visipena, 5(1) : 128-135.

Rofiah, Fiqratul. 2015. Defenisi Aktivitas Belajar, (Online), http://www.eurekapendidikan.c om/2015/10/definisi-aktivitasbelajar.html, Diakses Tanggal 12 September 2017 Pukul 20:33 WITA.

Santoso, F.G.I. Efektivitas Pembelajaran Berbasis Masalah Dan Group Investigation Terhadap Prestasi Belajar Matematika Ditinjau Dari Kecedasan Majemuk Siswa Kelas VII SMP Negeri Kota Madiun. Tesis tidak diterbitkan. Surakarta : Universitas Sebelas Maret.

Sufitriyani, Siti, 2013. Efektivitas Pembelajaran Matematika melalui Pendekatan Problem Solving pada Siswa Kelas XI IPA SMA Muhammadiyah 
Disamakan Di Wilayah Sulsel. Skripsi tidak diterbitkan. Makassar, Universitas Muhammadiyah Makassar.

Sukmadinata, Syaodih, Nana. 2016. Model kooperatif tipePeneltian Pendidikan. Bandung: Remaja Rosdakarya.

Slavin, E. 2016. Cooperatif Learning. Bandung: Nusa Media.

Suprijono, Agus. 2015. Cooperatif Learning. Yogyakarta: Pustaka Pelajar.

Suprihatiningrum. 2016. Strategi Pembelajaran. Yogyakarta: Arruzz Media.
Tampubolon, Saur. 2014. Penelitian Tindakan Kelas Sebagai Pengembangan Profesi Pendidik Dan Keilmuan. Jakarta : Erlangga

Tim Pustaka Phoenix. 2012. Kamus Besar Bahasa Indonesia. Jakarta. Media Pustaka Phoenix.

Tiro, M. A. 2008. Dasar - Dasar Statistika Edisi Ketiga. Makassar : Andira Publisher.

Trianto. 2011. Mendesain Model Pembelajaran InovatifProgresif. Jakarta: Kencana Media Group. 